\title{
Subclinical Hypothyroidism and Cardiovascular Risk- An Overview of Current Understanding
}

\author{
Ulla Feldt-Rasmussen, MD \\ Professor and Chief, Department of Medical Endocrinology, Rigshospitalet, National University Hospital, Copenhagen
}

DOI: $10.17925 /$ USE.2010.06.1.92

\begin{abstract}
Subclinical or mild hypothyroidism is often associated with adverse cardiovascular risk factors, such as high cholesterol, together with hypertension, endothelial dysfunction and other atherosclerotic cardiovascular risk factors. The ischemic abnormalities are probably related to long-term consequences of a slowly progressing development of hypothyroidism. In recent years, it has become evident that a consensus on the exact limits for cut-off between normal and subclinically hypothyroid individuals is not currently possible. The main reasons for this are differences for measurement of serum thyroid-stimulating hormone (TSH), that reference populations are very different, and that a person's intra-individual variability is much narrower than any population-based interval. Finally, the prevalence of subclinical hypothyroidism varies from 4 to $17 \%$ in different normal populations. Available evidence indicates that patients with subclinical hypothyroidism have developed or are at risk for developing an adverse cardiovascular profile, and subclinical hypothyroidism is most likely a mild variant of overt hypothyroidism. There is currently no evidence for a treatment benefit, but studies to demonstrate the expected minor improvements have not been performed on a sufficiently large scale. Patients should be informed about the disease and, based on a combined clinical and laboratory judgement, should be offered a therapeutic trial in case of even vague symptoms.
\end{abstract}

\section{Keywords}

Subclinical hypothyroidism, thyroid-stimulating hormone (TSH), decision level, reference population, cardiovascular, mortality, ischemic heart disease, thyroid hormone

Disclosure: The author has no conflicts of interest to declare.

Received: August 28, 2010 Accepted: October 1, 2010 Citation: US Endocrinology, 2010;6:92-6

Correspondence: Ulla Feldt-Rasmussen, MD, Department of Medical Endocrinology PE 2132, Rigshospitalet, National University Hospital, Blegdamsvej 9, DK-2100 Copenhagen,

Denmark. E: ufeldt@rh.dk

Subclinical hypothyroidism comrpsies elevated serum thyroid-stimulating hormone (TSH) in the context of normal peripheral thyroid hormone concentrations. ${ }^{1}$ Although this definition is highly dependant on methods for TSH measurement and the definition of the upper limit of normal reference values, many publications have come out in recent years concerning the long-term consequences of subclinical hypothyroidism and guidelines on its management have even been presented. ${ }^{2}$

Overt hypothyroidism is associated with abnormal hemodynamics resulting in a reduced cardiac index and an impaired renal perfusion, ${ }^{3}$ combined with adverse cardiovascular risk factors such as high total and low-density lipoprotein (LDL) cholesterol together with hypertension, endothelial dysfunction, increased central arterial stiffness and the other atherosclerotic cardiovascular risk factors. Even mild or subclinical hypothyroidism demonstrate these findings more often than do normal controls. ${ }^{1,2}$ All of the above factors may thus, in part, be responsible for a frequently described association between subclinical hypothyroidism and ischemic heart disease. This article aims to summarize the current understanding of the cardiovascular risks in mild or subclinical hypothyroidism, while other aspects of the condition such as its effects on cognitive function, fertility aspects and risks that develop during fetal brain development will not be dealt with here.

\section{The Case of Controversy in the Prevalence of Subclinical Hypothyroidism}

Overt hypothyroidism is diagnosed when the serum concentration of TSH is at or above $10 \mathrm{mU} /$ liter with a low serum thyroxine (T4) level, while patients with TSH levels between 4 and 10mU/liter, and serum triiodothyronine (T3) and T4 within the normal population-based reference range are defined as having mild (or subclinical) hypothyroidism. Subclinical or mild hypothyroidism is, however probably part of a continuum of thyroid function from normal individuals to overt hypothyroidism.

In recent years, it has become evident that a consensus on the exact limits for cut-off between normal and subclinically hypothyroid individuals is not around an immediate corner. ${ }^{4}$ There are several reasons for this. First, methods for measurement of TSH are highly different in terms of specificity, sensitivity, accuracy, and confounding 
Table 1: Studies on Overt $(\mathrm{OH})$ or Subclinical Hypothyroidism (H) and Outcome Compared with Euthyroid Controls

\begin{tabular}{|c|c|c|c|c|c|c|c|c|c|}
\hline Publication & Population & Type of Study & Number & Male/Female & Age (Years)* & $\begin{array}{l}\text { TSH Cut-off } \\
\text { Level (mU/I) }\end{array}$ & $\begin{array}{l}\text { Follow-up } \\
\text { (Years) }\end{array}$ & $\begin{array}{l}\text { Outcome } \\
\text { Measure }\end{array}$ & Result \\
\hline $\begin{array}{l}\text { Imaizumi } \\
\text { et al. }{ }^{19}\end{array}$ & Japanese & $\begin{array}{l}\text { Epidemiological } \\
\text { with euthyroid } \\
\text { controls }\end{array}$ & $\begin{array}{l}257(\mathrm{H}) \\
2,293(\mathrm{C})\end{array}$ & $96 / 61$ & $\begin{array}{l}\text { M } 62.7 \\
\text { F } 60.8\end{array}$ & $\begin{array}{l}5 \\
>10\end{array}$ & 10 & $\begin{array}{l}\text { Death } \\
\mathrm{IHD}^{* *}\end{array}$ & $\begin{array}{l}\text { RR } 2.2 \mathrm{M} \\
\text { Not significant F } \\
\text { RR } 3.6 \mathrm{M} 1.6 \mathrm{~F}\end{array}$ \\
\hline Parle et al. ${ }^{10}$ & UK & $\begin{array}{l}\text { Epidemiological } \\
\text { with euthyroid } \\
\text { controls }\end{array}$ & $\begin{array}{l}94(H) \\
1,026(C)\end{array}$ & $15 / 79$ & $\begin{array}{l}\text { M } 70 \text { (60-90) } \\
\text { F } 71(60-94)\end{array}$ & 5 & $\geq 10$ & Death & Not significant \\
\hline $\begin{array}{l}\text { Gussekloo } \\
\text { et al. }{ }^{16}\end{array}$ & Dutch & $\begin{array}{l}\text { Epidemiological } \\
\text { with euthyroid } \\
\text { controls }\end{array}$ & $\begin{array}{l}30(\mathrm{H}) \\
472(\mathrm{C})\end{array}$ & $189 / 369$ & 85 & 4.8 & 3 & Death & $\begin{array}{l}\text { RR } 0.77 \\
p<0.009\end{array}$ \\
\hline $\begin{array}{l}\text { Van den Beld } \\
\text { et al. }{ }^{17}\end{array}$ & Dutch & $\begin{array}{l}\text { Epidemiological } \\
\text { with euthyroid } \\
\text { controls }\end{array}$ & $\begin{array}{l}6(\mathrm{H}) \\
459(\mathrm{C})\end{array}$ & All males & $>73$ & 4.3 & 4 & Death & $\begin{array}{l}\text { Not } \\
\text { significant***}\end{array}$ \\
\hline $\begin{array}{l}\text { Walsh } \\
\text { et al. }{ }^{18}\end{array}$ & Australian & $\begin{array}{l}\text { Epidemiological } \\
\text { with euthyroid } \\
\text { controls }\end{array}$ & $\begin{array}{l}119(\mathrm{H}) \\
1,906(\mathrm{C})\end{array}$ & $\begin{array}{l}37 / 82 \\
994 / 912\end{array}$ & $\begin{array}{l}58 \\
49\end{array}$ & $\begin{array}{l}4.0 \\
>10\end{array}$ & 20 & $\begin{array}{l}\text { Death } \\
\text { IHD** }\end{array}$ & $\begin{array}{l}\text { Not significant } \\
\text { RR } 1.6<10 \mathrm{mU} / \mathrm{L} \\
\text { RR } 2.6>10 \mathrm{mU} / \mathrm{L}\end{array}$ \\
\hline $\begin{array}{l}\text { Cappola } \\
\text { et al. }{ }^{11}\end{array}$ & US & $\begin{array}{l}\text { Epidemiological } \\
\text { with euthyroid } \\
\text { controls }\end{array}$ & $\begin{array}{l}47(\mathrm{OH}) \\
51(\mathrm{H}) \\
2,639(\mathrm{C})\end{array}$ & $\begin{array}{l}21 / 30 \\
175 / 321 \\
1,096 / 1,543\end{array}$ & $>65$ & $\begin{array}{l}>20 \\
4.5\end{array}$ & 13 & $\begin{array}{l}\text { Death } \\
\text { IHD }\end{array}$ & $\begin{array}{l}\text { Not significant } \\
\text { Not significant }\end{array}$ \\
\hline $\begin{array}{l}\text { Sgarbi } \\
\text { et al. }{ }^{36}\end{array}$ & $\begin{array}{l}\text { Japanese- } \\
\text { Brazilian }\end{array}$ & $\begin{array}{l}\text { Epidemiological } \\
\text { with euthyroid } \\
\text { controls }\end{array}$ & $\begin{array}{l}99(\mathrm{H}) \\
913(\mathrm{C})\end{array}$ & $\begin{array}{l}36 / 63 \\
444 / 469\end{array}$ & $\begin{array}{l}58.5 \pm 12.3 \\
56.4 \pm 12.4\end{array}$ & 4.5 & 7 & Death $* * * *$ & RR $2.3 p<0.01$ \\
\hline Razvi et al. ${ }^{13}$ & UK & $\begin{array}{l}\text { Epidemiological } \\
\text { with euthyroid } \\
\text { controls }\end{array}$ & $\begin{array}{l}97(H) \\
2,279(C)\end{array}$ & $\begin{array}{l}23 / 74 \\
1,096 / 1,183\end{array}$ & $\begin{array}{l}49.9 \pm 17.9 \\
45.3 \pm 15.8\end{array}$ & $6-15$ & 20 & $\begin{array}{l}\text { Death } * * * * \\
\text { IHD death }\end{array}$ & $\begin{array}{l}\text { Not significant } \\
\text { RR } 1.8 \\
p<0.5\end{array}$ \\
\hline
\end{tabular}

*Mean and/or range. **No proof of association between subclinical hypothyroidism and cardiovascular death. ***Very small number and only males. ****All-cause mortality. $C=$ euthyroid controls; $F=$ female; $H=$ subclinical hypothroidism; $M=$ male; $O H=$ overt hypothyroidism; $R R=$ relative risk; TSH = thyroid-stimulating hormone.

influences such as heterophilic antibodies; second, reference populations used as the basis for a normal range are highly different in terms of e.g. iodine intake, age, gender, and presence of thyroid autoantibodies, and should not be confused with cut-off limits; ${ }^{5}$ third, even if the clinical and scientific community could agree on those two points there would still be a large inter-individual variability compared with the person's own variability in thyroid function variables over time (intra-individual variability), implying that one combination of TSH-T4 could mean euthyroidism in one individual and subclinical hypothyroidism in another. ${ }^{6}$ These differences in defining the condition are also part of the reason for the reported prevalence of subclinical hypothyroidism varying from 4 to $17 \%$ of a normal population.

Some of the above controversial issues are elegantly considered in an article by Beckett and MacKenzie, ${ }^{7}$ accompanied by an editorial by Weetman. ${ }^{8}$ Their review of current guidelines highlighted another often overlooked reason for circumspection in using apparently precise TSH decision limits for treatment recommendations. As they pointed out, the reasons for having guidelines is to simplify and standardize treatment. The danger in simplification is obvious in that it fails to take the patient as an individual into account, as is frequently made clear in ripostes to the onslaught of evidence-based medicine. It also must be admitted that much evidence will never be gathered in areas of established clinical endocrinology practice, while in others such as the evidence supporting treatment of subclinical hypothyroidism, there are still surprising gaps and uncertainties ${ }^{6}$ that may for other reasons never be investigated in the full evidence-based manner (see below).

\section{Cardiac Morbidity and Mortality in Subclinical Hypothyroidism}

Although it is the general clinical impression that patients with overt hypothyroidism have increased cardiac morbidity and mortality, real evidence is scarce. More controversial is the morbidity and mortality when considering mild or subclinical hypothyroidism. Most available evidence is based on surrogate markers such as adverse lipid profile, endothelial dysfunction, increased arterial stiffness, and cardiac performance. ${ }^{6,9}$

However, some population studies have provided a reasonable level of evidence for the mortality and cardiovascular morbidity rates in hypothyroidism (see Table 1). As seen in Table 1, the studies are widely different both in population selection, follow-up period and definition of the degree of thyroid dysfunction (by choice of TSH decision levels). The general picture from these studies is that of only a questionable or at best minor association between hypothyroidism and cardiovascular death, although many of them do find an association with cardiovascular risk. A large population study from the $\mathrm{UK}^{10}$ of a 10-year follow-up of 1,191 persons in the community over 60 years of age described no association between raised serum TSH at screening and higher mortality, quite the opposite to persons with suppressed TSH. Similarly, the large cross-section Cardiovascular Health Study from the US including 3,678 subjects found no increased cardiovascular morbidity in those with subclinical hypothyroidism compared with those with normal TSH levels, ${ }^{11}$ and the 20-year follow-up of 2,779 subjects from the Wickham study ${ }^{12}$ did not find such association either. However, 
Table 2: Recent Trials on T4 Replacement of Subclinical Hypothyroidism on Cardiac Risks

\begin{tabular}{|c|c|c|c|}
\hline Study & $\begin{array}{l}\text { Type of } \\
\text { Study (n) }\end{array}$ & $\begin{array}{l}\text { Duration } \\
\text { (Months) }\end{array}$ & Result \\
\hline Nagasaki et al. ${ }^{37}$ & $\begin{array}{l}\text { RCT } \\
\text { (50 in each } \\
\text { group) }\end{array}$ & 5 & $\begin{array}{l}\text { Decrease in brachial- } \\
\text { ankle pulse wave }\end{array}$ \\
\hline Oflaz et al. ${ }^{38}$ & $\begin{array}{l}\% \mathrm{RCT} \\
(10)\end{array}$ & 6 & $\begin{array}{l}\text { Increased coronary } \\
\text { flow reserve }\end{array}$ \\
\hline Teixera et al. ${ }^{39}$ & $\begin{array}{l}\text { RTC } \\
\text { (30 in each } \\
\text { group) }\end{array}$ & 6 & $\begin{array}{l}\text { Decreased total and } \\
\text { LDL cholesterol }\end{array}$ \\
\hline Tagami et al. ${ }^{40}$ & $\begin{array}{l}\% \text { RCT } \\
(32)\end{array}$ & 3 & $\begin{array}{l}\text { Decreased total and } \\
\text { LDL cholesterol }\end{array}$ \\
\hline Kim et al. ${ }^{41}$ & $\begin{array}{l}\% \mathrm{RCT} \\
(36)\end{array}$ & 12 & Decreased C-IMT \\
\hline Texeira et al. ${ }^{42}$ & $\begin{array}{l}\text { RCT (11 T4, } \\
15 \text { placebo) }\end{array}$ & 12 & $\begin{array}{l}\text { Decreased atherogenic } \\
\text { lipids }\end{array}$ \\
\hline Baldini et al. ${ }^{43}$ & $\begin{array}{l}\text { \% RCT } \\
\text { (38, euthyroid } \\
\text { controls) }\end{array}$ & 6 & $\begin{array}{l}\text { Increased QoL } \\
\text { Decreased total and } \\
\text { LDL cholesterol }\end{array}$ \\
\hline Peleg et al. ${ }^{44}$ & $\begin{array}{l}\% \mathrm{RCT} \\
(30)\end{array}$ & 7 & $\begin{array}{l}\text { Decreased arterial } \\
\text { stiffness }\end{array}$ \\
\hline
\end{tabular}

$C-I M T=$ carotid artery intima media thickness; $L D L=$ low-density lipoprotein; $Q O L=$ quality of life; $R T C=$ randomized controlled trial.

in a recent re-analysis of this cohort ${ }^{13}$ with exclusion of individuals with known thyroid disease or ischemic heart disease and on medications that could affect thyroid function, the majority of participants at baseline were euthyroid (95.9\%; mean age 45.3 years, range 18-92). The prevalence of subclinical hypothyroidism (between 6 and 15mU/liter) was $4.1 \%$ (mean age 49.9 years, range 18-87) and was higher in women, older individuals, non-smokers, and those with positive thyroid antibodies. These patients had a higher mortality rate from ischemic heart disease with a relative risk (RR) of approximately 1.8 . Furthermore, in a cross-sectional study of 1,149 women aged $69 \pm 7.5$ years from Rotterdam Hak et al. ${ }^{14}$ described an increased risk for atherosclerosis and acute myocardial infarction in subjects with subclinical hypothyroidism defined as serum TSH >4.0mU/liter and normal levels of $\mathrm{T} 4$ and $\mathrm{T} 3$, but there were no data on mortality.

Other recent publications also focused on subclinical hypothyroidism in elderly subjects. Among 3,233 persons aged 65+ followed for 12 years, 496 (15\%) had subclinical hypothyroidism. No difference was found concerning cardiovascular outcomes or mortality in subclinical hypothyroidism compared with overt hypothyroidism or euthyroid controls (adjusted hazard ratio 1.07; 95\% confidence interval $[\mathrm{Cl}]$ 0.9-1.28). ${ }^{13}$ Among 558 persons from Leiden aged 85 years, 67 (13\%) had subclinical hypothyroidism (here defined with $\mathrm{TSH}>4.8 \mathrm{mU} /$ liter). They were followed for four years and the mean annual mortality rate was lower in those with subclinical hypothyroidism compared with both those with low and normal TSH levels. ${ }^{15}$ Gussekloo et al. found similar results. ${ }^{16}$ Van den Beld studied 403 men (73-94 years) from Rotterdam for four years and found a significantly lower mean annual mortality rate in those with a low free T4 level compared with those with a normal or high free T4. In the paper it was suggested that a low T4 level should represent an adaptive mechanism to prevent excessive catabolism. ${ }^{17}$
Walsh et al. ${ }^{18}$ found a significant relationship between subclinical hypothyroidism and ischemic heart disease, but no relationship between subclinical hypothyroidism and mortality in Australia.

In contrast to the above-mentioned reports, a Japanese study using Kaplan-Meier survival curves that the all-cause survival rate was lower in 257 men with subclinical hypothyroidism (TSH above $5.0 \mathrm{mU} /$ liter) than in the 2,293 controls, but no similar difference was apparent in women. They assumed that the increased mortality was due to an increase in ischemic heart disease, although this was not investigated. ${ }^{19}$

\section{Meta-analyses and Structured Review of Mortality Data in Subclinical Hypothyroidism}

Rodondi et al. performed a meta-analysis of 14 observational studies ${ }^{20}$ and found that subclinical hypothyroidism was associated with increased risk for coronary heart disease (odds ratio (OR) 1.65; 95\% $\mathrm{Cl}$ 1.28-2.12), but there was no mentioning of mortality and no clinical trials of replacement. The conclusion was that clinical trials are needed to assess whether T4 replacement reduces the risk for coronary heart disease in subjects with subclinical thyroid disease.

In another meta-analysis Ochs et al. ${ }^{21}$ used a random-effects model and found the RR for subclinical hypothyroidism for ischemic heart disease at 1.20 (95\% Cl 0.97-1.49; p for heterogeneity 0.14 ; I(2) 33.4\%). Risk estimates were lower when higher-quality studies were pooled (RR 1.02-1.08) and were higher among participants younger than 65 years. The RR was $1.18(\mathrm{Cl} 0.98-1.42)$ for cardiovascular mortality and $1.12(\mathrm{Cl} 0.99-1.26)$ for total mortality. They concluded that subclinical hypothyroidism may be associated with a modest increased risk for ischemic heart disease and mortality, with lower risk estimates when pooling higher-quality studies.

Razvi et al. conducted a third meta-analysis on the influence of age on the relationship between subclinical hypothyroidism and ischemic heart disease. ${ }^{22}$ Fifteen studies with a total of 2,531 patients with subclinical hypothyroidism and 26,491 euthyroid individuals were included. Both incidence and prevalence of ischemic heart disease were higher in subclinical hypothyroidism compared with euthyroid persons from studies including those below 65 years of age, but not in studies of subjects above 65 years: OR $1.57(95 \% \mathrm{Cl} 1.19-2.06)$ versus 1.01 $(95 \% \mathrm{Cl} 0.87-1.18)$ and $\mathrm{OR} 1.68(95 \% \mathrm{Cl} 1.27-2.23)$ versus $1.02(95 \% \mathrm{Cl}$ $0.85-1.22)$, respectively. Cardiovascular and all-cause mortality was also elevated in studies of those $>65$ years of age, but not from studies of older people: OR $1.37(95 \% \mathrm{Cl} 1.04-1.79)$ versus 0.85 (0.56-1.29). Prevalent ischemic heart disease was higher in subclinical hypothyroidism of both genders, but statistically significant only in women. They concluded that subclinical hypothyroidism was associated with increased ischemic heart disease (both prevalence and incidence) and cardiovascular mortality only in subjects from younger populations, and these data thus suggest that increased vascular risk may only be present in younger individuals with subclinical hypothyroidism.

A fourth comparative review by Haentjens et al. ${ }^{23}$ looked at nine cohorts including 1580 participants with subclinical hypothyroidism, and noted that observed heterogeneity $(Q$ test $p=0.006 ; 1(2)=63 \%)$ disappeared 
after pooling cohorts in pre-defined subgroups according to the presence or absence of a comorbid condition. In doing so, the pooled HR for all-cause mortality was $1.03(95 \% \mathrm{Cl} 0.78-1.35, \mathrm{p}=0.83)$ in cohorts from the community and $1.76(95 \% \mathrm{Cl} 1.36-2.30, \mathrm{p}<0.001)$ in cohorts of participants with comorbidities ( $p=0.014$ for heterogeneity among study groups). Their conclusion was that for patients with subclinical hypothyroidism, the relative risk for all-cause mortality was increased only in patients with comorbid conditions.

\section{Levothyroxine Supplementation in Patients with Subclinical Hypothyroidism- Does It Improve Cardiac Risk?}

It is usually accepted that overt hypothyroidism should be treated with T4 replacement, although evidence for a reduced mortality and morbidity by T4 therapy of hypothyroid patients with cardiovascular disease is still lacking after more than 50 years of treating this frequent condition. It is more controversial whether mild (or subclinical) hypothyroidism should be treated, since available evidence of a link between subclinical hypothyroidism and cardiac morbidity and mortality is not very clear, as mentioned above, and no trials have been able to show a clear benefit. ${ }^{9,24}$

Most of the papers on treatment of subclinical hypothyroidism with T4 have dealt only with surrogate markers. Recent trials are listed in Table 2. Thus, Meier et al. ${ }^{25}$ undertook a randomized placebo-controlled trial of 66 women (18-75 years, 49 of them post-menopausal) with subclinical hypothyroidism (mean TSH $11.7 \mathrm{mU} / \mathrm{liter}$ ) and treatment with L-T4 for 48 weeks. They found a significant lowering of LDL cholesterol and clinical symptoms of hypothyroidism, as estimated by scores developed by Zulewski et al.., ${ }^{26}$ and predicted a 9-31\% risk reduction in cardiovascular mortality. Caraccio et al. ${ }^{27}$ studied 49 patients (mainly women) aged $18-50$ years with $\mathrm{TSH}>3.6 \mathrm{mU} /$ liter (of whom, 12 had TSH concentration $>6 \mathrm{mU} /$ liter). They found a modest decrease in the level of triglyceride and LDL cholesterol in the T4-treated group and no change in the placebo group, and with a calculated risk reduction of approximately 15\% in ischemic heart disease. However, the calculation was, based on data from males only, while no data were available for females, and, furthermore, mortality was not investigated. Other randomized studies have provided conflicting results on the effects on symptoms of hypothyroidism when treated with T4. ${ }^{28-30}$ In non-randomized studies, an increased risk for atherosclerosis has been estimated by pulse wave velocity in patients with varying degrees of hypothyroidism ${ }^{31,32}$ and this effect was reversed in one of the studies with appropriate thyroxine treatment. ${ }^{32}$

A Cochrane review of treatment of subclinical hypothyroidism was carried out by Villar et al. ${ }^{33}$ Twelve randomized controlled trials (RCTs) ( $n=485,75 \%$ women) met the selection criteria, and all of them compared T4 replacement with placebo (11 RCTs) or no treatment (one

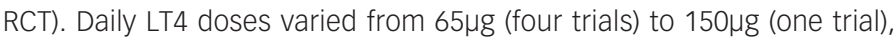
and study duration varied between six and 14 months. All trials were of moderate or good quality (Jadad scale $>3$ ). The TSH decision level was highly variable among methods. None of the trials reported on mortality (cardiovascular or all-cause) or cardiovascular morbidity, and groups did not differ in any trial with respect to hypothyroid signs and symptoms (seven trials), quality of life (two trials), or adverse effects (four trials). In one trial $(n=66)$, thyroid hormone replacement improved cognitive function (weighted mean difference 2.4, 95\% Cl 0.3-4.5, $\mathrm{p}=0.03$ ). The general conclusion was that in adults with subclinical hypothyroidism, evidence does not support a benefit for thyroid hormone replacement therapy. This conclusion has been extensively commented, e.g. by Gharib et al., ${ }^{34}$ who found it premature to conclude that all patients with subclinical hypothyroidism should not be treated with thyroid replacement therapy. He stressed the importance to remember that "lack of definitive evidence for a benefit does not equate to evidence for lack of benefit." Mild hypothyroidism, usually defined by an approximate serum TSH of $5-10 \mathrm{mIU} /$ liter, is expected to have milder symptoms, and demonstration of beneficial treatment effects would accordingly require very large patient groups and much longer treatment periods. According to Dr. Gharib: "Physicians taking care of these patients need the flexibility to exercise their best clinical judgment in each case," which is in keeping with a similar statement from Weetman on the same topic but here mainly in the view of the difficulty to base clinical decisions on studies using very different-and in many cases no longer available-TSH assays. ${ }^{7.8}$

\section{The Case for Treatment of Subclinical Hypothyroidism}

The main arguments are that the patients have or are at risk for developing an adverse cardiovascular profile, subclinical hypothyroidism is most likely a mild variant of overt hypothyroidism, and some patients will feel much better after replacement therapy. Patients should be informed about the disease and possible improvement (or not) by treatment. In each case it is important to ensure the diagnosis (test for heterophilic antibodies, send sample to another laboratory using a different commercial kit), measure antithyroid peroxidase (TPO) antibodies, check serum TSH at follow-up within three to six months and subsequently once or twice a year. In case of even vague symptoms, objective findings and/or patient request, make a therapeutic trial of levothyroxine. For most clinicians it is important to know that TSH decision levels in one publication are not necessarily the same as in another and the laboratory bias of different TSH measurements is often unknown. ${ }^{7.8}$ In other words, a published TSH decision level of e.g. $7.5 \mathrm{mU} /$ liter in your own laboratory using a different method might be 4.5 or $10 \mathrm{mu} /$ liter, and thus be your cut-off for subclinical or overt hypothyroidism.

\section{Conclusions}

Most of the studies of subclinical hypothyroidism are observational, and it does not always follow that treatment of subclinical hypothyroidism will reduce the risk for cardiovascular disease and mortality. To demonstrate such a benefit would require very large clinical trials with a long follow-up period. Ideally, randomized placebo-controlled clinical trials of levothyroxine therapy in different patient groups should be performed. The most important outcome measures should include both hard end-points such as mortality, but also general morbidity, cost-effectiveness and quality of life..$^{35}$ The latter may be important in particular in elderly patients with co-existing heart disease, who may not benefit subjectively from levothyroxine treatment and whose long-term protection from future deterioration of cardiovascular disease by levothyroxine therapy could be overestimated and even questioned. However, such studies on the effects of treatment of subclinical hypothyroidism are very unlikely to be conducted as 


\section{Thyroid Disorders}

investigator-initiated trials due to the costs, and it is doubtful whether such a trial could attract sufficient interest from the pharmaceutical industry. Evidence-based management of subclinical hypothyroidism may thus also in the future have to be based on epidemiological studies and on clinical trials with surrogate cardiovascular end-points.

In the view of the author, available evidence speaks for treatment (or at least performing a therapeutic trial of at least six months' duration) of subclinical hypothyroidism in most patients $<65$ years of age. Higher age is not a contraindication in itself, but caution is prudent in elderly persons. A clinician's pragmatic approach would be to give the patient a chance of improved quality of life and cognition and reduced cardiovascular morbidity. Probably the risk for overtreatment is highly overrated.

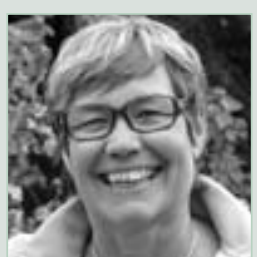

Ulla Feldt-Rasmussen, MD, is a Professor at the University of Copenhagen and Chief of Medical Endocrinology at the National University Hospital in Copenhagen. Her research interests involve the thyroid gland and autoimmunity, as well as pituitary dysfunction. She has recently also focused on the detrimental effects of lack of thyroid hormone and the benefit of replacement at all age groups, from pre-conception to elderly individuals. Dr Feldt-Rasmussen has published more than 270 papers in peer-reviewed journals and belongs to numerous international professional organizations including The Endocrine Society, the European Thyroid Association (ETA), the American Thyroid Association (ATA), the European Neuroendocrine Association (ENEA), and the Growth Hormone Research Society (GRS), and she has served as Secretary-Treasurer of the ETA and is President of the ETA Cancer Research Network.
1. Biondi B, Palmieri EA, Lombardi G, Fazio S, Subclinical hypothyroidism and cardiac function, Thyroid, 2002;12:505-10.

2. Surks Ml, Ortiz E, Daniels GH, et al., Subclinical thyroid disease. Scientific review and guidelines for diagnosis and management, JAMA, 2004;291:228-38.

3. Klein I, Ojamaa K, The cardiovascular system in hypothyroidism, In: Braverman LE, Utiger RD (eds), Werner \& Ingbar's The Thyroid: A Fundamental and Clinical Text, edn. 8, Philadelphia: Lippincott Williams \& Wilkins, 2000;777-82.

4. Brabant G, Beck-Peccoz P, Jarzab B, et al., Is there a need to redefine the upper normal limit of TSH?, Eur J Endocrinol, 2006;154:633-7.

5. Waise $\mathrm{A}$, Price $\mathrm{HC}$, The upper limit of the reference range for thyroid-stimulating hormone should not be confused with a cut-off to define subclinical hypothyroidism, Ann Clin Biochem, 2009:46:93-8.

6. Feldt-Rasmussen $\mathrm{U}$, Hyltoft Petersen $\mathrm{P}$, Blaabjerg $\mathrm{O}$, Hørder $\mathrm{M}$, Long-term variability in serum thyroglobulin and thyroid related hormones in healthy subjects, Acta Endocrinol (Copenh), 1980;95:328-34.

7. Beckett G, Mackenzie F, Thyroid guidelines are thyroid-stimulating hormone assays fit for purpose? Ann Clin Biochem, 2007;44(3):203-8.

8. Weetman AP, Thyroid-stimulating hormone assays: guidelines, guidance and clinical judgement, Ann Clin Biochem, 2007:44:201-2.

9. Fazio S, Palmieri EA, Lombardi G, Biondi B, Effects of thyroid hormone on the cardiovascular system, Recent Progr Horm Res, 2004;59:31-50.

10. Parle JV, Maisonneuve P, Sheppard MC, et al., Prediction of all-cause and cardiovascular mortality in elderly people from one low serum thyrotropin result: a 10 year cohort study, Lancet, 2001;358:861-5.

11. Cappola AR, Fried LP, Arnold AM, et al., Thyroid status, cardiovascular risk, and mortality in older adults, JAMA, 2006:295:1033-41.

12. Vanderpump MP, Tunbridge WM, French JM, et al., The development of ischemic heart disease in relation to autoimmune thyroid disease in a 20-year follow-up study of an English community, Thyroid, 1996;6:155-60.

13. Razvi S, Weaver JU, Vanderpump MP, Pearce SHS, The incidence of ischemic heart disease and mortality in people with subclinical hypothyroidism: reanalysis of the Whickham survey cohort, J Clin Endocrinol Metab, 2010;95:1734-40.

14. Hak AE, Pols HA, Visser TJ, et al., Subclinical hypothyroidism is an independent risk factor for atherosclerosis and myocardial infarction in elderly women: the Rotterdam study, Ann Int Med, 2000;132:270-8.

15. Singer RB, Mortality in a complete 4-year follow up of 85-year-old residents of Leiden, classified by serum level of thyrotropin and thyroxine, J Insur Med, 2006;38:14-9.

16. Gussekloo J, van Exel E, de Craen AJM, et al., Thyroid status, disability and cognitive function, and survival in old age,
JAMA, 2004;292:2591-9.

17. Van den Beld AW, Visser TJ, Fedders RA, et al., Thyroid hormone concentrations, disease, physical function, and mortality in elderly men, I Clin Endocrinol Metab, 2005;90: 6403-9.

18. Walsh JP, Bremner AP, Bulsara MK, et al., Subclinical thyroid dysfunction as a risk factor for cardiovascular disease, Arch Intern Med, 2005;165:2467-72

19. Imaizumi $\mathrm{M}$, Akahoshi $\mathrm{M}$, Ichimaru $\mathrm{S}$, et al., Risk for ischemic heart disease and all-cause mortality in subclinica hypothyroidism, J Clin Endocrinol Metab, 2004:89: 3365-70.

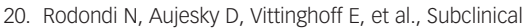
hypothyroidism and the risk of coronary heart disease: a meta-analysis, Am J Med, 2006;119:541-51.

21. Ochs N, Auer R, Bauer DC, et al., Meta-analysis: subclinica thyroid dysfunction and the risk for coronary heart disease and mortality, Ann Intern Med, 2008;148:832-45.

22. Razvi S, Shakoor A, Vanderpump M, et al., The influence of age on the relationship between subclinical hypothyroidism and ischemic heart disease: a meta-analysis, J Clin Endocrino Metab, 2008;93:2998-3007.

23. Haentjens $P$, Van Meerhaeghe A, Poppe $K$, Velkeniers B, Subclinical thyroid dysfunction and mortality: an estimate of relative and absolute excess all-cause mortality based on time-to-event data from cohort studies, Eur J Endocrinol 2008;159:329-41.

24. Boelaert K, Franklyn JA, Thyroid hormone in health and disease, J Endocrinol, 2005;187:1-15.

25. Meier C, Staub JJ, Roth CB, et al., TSH-controlled L-thyroxine therapy reduces cholesterol levels and clinical symptoms in subclinical hypothyroidism: a double-blind, placebo-controlled trial (Basel Thyroid Study), I Clin Endocrino Metab, 2001:86:4860-6.

26. Zulewski H, Müller B, Exer P, Miserez AR, Staub JJ, Estimation of tissue hypothyroidism by a new clinical score: Evaluation of patients with various grades of hypothyroidism and controls, J Clin Endocrinol Metab, 1997:82:771-6.

27. Caraccio N, Ferrannini E, Monzani F, Lipoprotein profile in subclinical hypothyroidism: response to levothyroxine replacement, a randomised placebo-controlled study, I Clin Endocrinol Metab, 2002;87:1533-8.

28. Nyström $E$, Caldahl $K$, Fager $G$, et al., A double-blind cross-over 12-month study of L-thyroxine treatment of women with 'subclinical' hypothyroidism, Clin Endocrinol (Oxf), 1988;29:63-75

29. Cooper DS, Halpern R, Wood LC, et al., L-thyroxine therapy in subclinical hypothyroidism. A double-blind, placebo-controlled trial, Ann Intern Med, 1984:101:18-24.

30. Jaeschke R, Guyatt $G$, Gersten $H$, et al., Does treatment with L-thyroxine influence health status in middle-aged and older adults with subclinical hypothyroidism?, J Gen Intern Med, 1996;11:744-9.
31. Dagre AG, Lekakis JP, Papaioannou TG, et al., Arterial stiffness is increased in subjects with hypothyroidism, Int Cardiol, 2005;103:1-6.

32. Hamano $\mathrm{K}$, Inoue $\mathrm{M}$, Increased risk for atherosclerosis estimated by pulse wave velocity in hypothyroidism and its reversal with appropriate thyroxine treatment, Endocr J, 2005;52:95-101

33. Villar $\mathrm{HC}$, Saconato $\mathrm{H}$, Valente $\mathrm{O}$, Atallah AN, Thyroid hormone replacement for subclinical hypothyroidism, Cochrane Database Syst Rev, 2007;18:CD003419

34. Gharib H, Review: available evidence does not support a benefit for thyroid hormone replacement in adults with subclinical hypothyroidism, Evid Based Med, 2008;13:22.

35. Watt T, Groenvold M, Rasmussen AK, et al., Quality of life in patients with benign thyroid disorders. A review, Eur J Endocrinol, 2006:154:501-10

36. Sgarbi JA, Matsumura LK, Kasamatsu TS, et al., Subclinica thyroid dysfunctions are independent risk factors for mortality in a 7.5-year follow-up: the Japanese-Brazilian thyroid study, Eur J Endocrinol, 2010;162:569-77.

37. Nagasaki T, Inaba M, Yamada S, et al., Decrease of brachial-ankle pulse wave velocity in female subclinical hypothyroid patients during normalization of thyroid function: a double-blind, placebo-controlled study, Eur J Endocrinol, 2009:160:409-15.

38. Oflaz H, Kurt R, Sen F, et al., Coronary flow reserve after L-thyroxine therapy in Hashimoto's thyroiditis patients with subclinical and overt hypothyroidism, Endocrine, 2007;32: 264-70.

39. Teixeira PF, Reuters VS, Ferreira MM, et al., Treatment of subclinical hypothyroidism reduces atherogenic lipid levels in a placebo-controlled double-blind clinical trial, Horm Metab Res, 2008;40:50-5

40. Tagami T, Tamanaha T, Shimazu S, et al., Lipid profiles in the untreated patients with Hashimoto thyroiditis and the effects of thyroxine treatment on subclinical hypothyroidism with Hashimoto thyroiditis, Endocr J, 2010;57:253-8.

41. Kim SK, Kim SH, Park KS, et al., Regression of the increased common carotid artery-intima media thickness in subclinical hypothyroidism after thyroid hormone replacement, Endocr J, 2009;56:753-8.

42. Teixeira PF, Reuters VS, Ferreira MM, et al., Lipid profile in different degrees of hypothyroidism and effects of levothyroxine replacement in mild thyroid failure, Trans/ Res, 2008;151:224-31.

43. Baldini M, Colasanti A, Orsatti A, et al., Neuropsychological functions and metabolic aspects in subclinical hypothyroidism: the effects of L-thyroxine, Prog Neuropsychopharmacol Biol Psychiatry, 2009;33:854-9.

44. Peleg RK, Efrati S, Benbassat C, Fygenzo M, Golik A, The effect of levothyroxine on arterial stiffness and lipid profile in patients with subclinical hypothyroidism, Thyroid, 2008;18:825-30 